\title{
Nitrergic Neuron
}

National Cancer Institute

\section{Source}

National Cancer Institute. Nitrergic Neuron. NCI Thesaurus. Code C12647.

A nerve cell that uses nitric oxide as its neurotransmitter. 